\title{
Da liberdade e da necessidade, ou das ações voluntárias em Hume
}

Maria Adriana Camargo Cappello

Professora de filosofia na UFPR 

O tema da liberdade aparece, em Hume, no contexto do tratamento das paixões que ele classifica como diretas, aquelas "impressões que resultam imediatamente do mal e do bem, da dor e do prazer", como o desejo e a aversão, a tristeza e a alegria, a esperança e o medo. E será neste contexto das paixões que o tema da liberdade aparecerá como um natural desenvolvimento do tratamento de uma paixão sui generis, a saber, a vontade. Como nota Hume, ainda que não possa ser rigorosamente concebida como uma paixão, a vontade é, "dentre todos os efeitos imediatos da dor e do prazer, o mais notável” (Hume 2001. L. II, P. III, sec. I). É assim que, enquanto paixão, impressão de reflexão, ou, ainda, efeito das afecções de dor e prazer, a vontade nos é apresentada por Hume, desde o início, não como uma faculdade, responsável pela atividade autônoma do sujeito, mas, antes, como uma passividade por ele sofrida, a partir da qual, somente, se encetaria uma reação ou, se quisermos, uma ação motivada. Enquanto paixão, a vontade envolve, no entanto, uma consciência de deliberação. Por vontade, Hume nos diz entender simplesmente "a impressão interna que sentimos e de que temos consciência quando deliberadamente (knowingly) geramos um novo movimento em nosso corpo ou uma nova percepção em nossa mente" (Id., Ibid.). ${ }^{.}$À primeira vista,tudo se passa como se uma deliberação fosse feita após impressões de dor ou de prazer, gerando uma resposta, positiva ou negativamente, a essas impressões. Ainda que, como defenderemos adiante, há uma qualificação desse processo proveniente de sua complexidade, desde já, no entanto, podemos adiantar que a vontade como geração deliberada de um movimento ou percepção se distingue daquela mesma deliberação pela qual a vontade é caracterizada, no contexto de toda uma tradição metafísica, como um poder de agir ou não agir, como uma faculdade de escolha absoluta do sujeito.

1 "I desire it may be observed, that by the will, I mean nothing but the internal impression we feel and are conscious of, when we knowingly give rise to any new motion of our body, or new perception of our mind." 
De fato, o leitor que chegou até este momento da exposição do pensamento de Hume, seja no Tratado, seja, posteriormente, na Investigação, não poderia esperar outra coisa. O contexto, como sabemos, é o do empirismo, no qual se desenvolverá uma investigação que se interdita qualquer postulação de entidades metafísicas, tanto no que se refere à matéria, quanto no que se refere ao espírito. O dado, do qual se parte, é o do fluxo do sensível, imagens discerníveis e distintas entre si. A mente, também enquanto dado, é, originalmente imaginação, apreensão e reprodução de imagens que, no entanto, são apreendidas qualitativamente, isto é, como dor ou prazer. Ocorre, ainda, que a reprodução dessas imagens se dá segundo determinados princípios, e que as próprias afecções que acompanham estas imagens passam a configurar uma finalidade - evitar a dor, procurar o prazer - pelo que a mente, ou este feixe de impressões e ideias, passa a ganhar uma certa uniformidade, o que lhe dá uma certa constituição, uma certa natureza. E é porque esta mente, naturalizada, se individualiza enquanto conjunto de ideias e impressões, que a compõem segundo coordenadas espaço-temporais, que ela se torna sujeito, ganha individualidade.

Sendo assim, o sentido mais original dessa experiência, da qual trata o empirismo de Hume, diz respeito, como nos ensina Deleuze (2007), mais do que apenas ao dado, mais do que, também, à coleção de imagens que constitui a mente, ou à imaginação, a estes dados colocados sob a uniformidade de certas relações, a partir da atuação de certos princípios. É nesse sentido que o empirismo de Hume, mais do que uma investigação que parte e se funda na experiência, caracteriza-se como uma investigação que diz respeito à constituição mesma da experiência, a partir do dado, e à constituição do sujeito, a partir da mente. E é nesse sentido, ainda, e no que diz respeito a nossa questão, que esta investigação, de cunho empirista e que visa, antes de tudo, à constituição do sujeito e de sua ciência, pode ser compreendida também por sua crítica às metafísicas materialistas e idealistas. 
Crítica ao idealismo na medida em que não parte da substancialidade do sujeito, mas, ao contrário, a ele deve chegar. Crítica ao materialismo, pois, se não se considera um sujeito prévio, também não se considera uma Natureza prévia, que se distinguiria de suas representações por um sujeito. A esse respeito, mais uma vez, o ponto de partida é o dado, que não são coisas, objetos, mas impressões. As ideias são cópias de impressões, e não de coisas, ou seja, elas também não remetem a uma natureza com poderes ocultos, as chamadas qualidades primárias, que elas apenas representariam mediante as chamadas qualidades secundárias. Se as ideias copiam as impressões, com perda de nitidez e vivacidade, é verdade, elas não as representam, ou seja, não há entre elas a distinção de natureza que haveria entre as coisas e suas ideias. Se, por outro lado, a existência de uma Natureza distinta do conjunto de impressões e ideias é admitida, ela não é objeto da ciência que então se desenvolve ${ }^{2}$, sua possível essência interior é deixada de fora do campo de investigação, assim como a da própria mente já o havia sido. Donde a circunscrição do objeto de investigação de Hume, seu objetivo de construir uma ciência do homem, que se furta a investigar tanto a essência do espírito quanto a essência da Natureza, para se ater à formação, no campo do dado, mediante a atuação de certos princípios que se observam aplicados a estes mesmos dados, de uma natureza, a natureza humana.

... ao pretender explicar os princípios da natureza humana, estamos de fato propondo um sistema completo das ciências, construindo sobre um fundamento quase inteiramente novo, e o único sobre o qual elas podem se estabelecer com alguma segurança. Assim como a ciência do

2 "É certo que a mente, em suas percepções, tem de começar de algum lugar; e, uma vez que as impressões precedem suas ideias correspondentes, é preciso que algumas impressões apareçam na alma sem que nada as introduza. Mas essas impressões dependem de causas naturais e físicas, e seu exame me afastaria muito de meu tema presente, levando-me até as ciências da anatomia e filosofia da natureza." (Hume 2001. L.II, P.I., sec. I). 
homem é o único fundamento sólido para as outras ciências, assim também o único fundamento sólido que podemos dar a ela deve estar na experiência e na observação. (...) Parece-me evidente que a essência da mente sendo-nos tão desconhecida quanto a dos corpos externos, deve ser igualmente impossível formar qualquer noção de seus poderes e qualidades de outra forma que não seja por meio de experimentos cuidadosos e precisos, e da observação dos efeitos particulares resultantes de suas diferentes circunstâncias e situações. Embora devamos nos esforçar para tornar todos os nossos princípios tão universais quanto possível (...) qualquer hipótese que pretenda revelar as qualidades originais e últimas da natureza humana deve imediatamente ser rejeitada como presunçosa e quimérica (Hume 2001, Intr., p. 22-23).

E é, portanto, no contexto desta "observação dos efeitos particulares resultantes de suas diferentes circunstâncias e situações" que, como sabemos, Hume dedicará todo o Livro I do Tratado para descrever a atuação dos princípios sobre um determinado conjunto de percepções que constituem a mente. Mais especificamente, a atuação dos princípios no estabelecimento de relações entre as impressões de sensação e as ideias delas provenientes, bem como do surgimento de determinadas impressões de reflexão específicas, como a da crença na existência contínua e independente dos objetos, que é fundamento de toda nossa ciência da matéria, de toda a nossa Física. E que, na sequência, Hume dedicará o Livro II para a descrição das relações entre as impressões de reflexão, as paixões, que dizem respeito ao "interesse que temos por nós mesmos" (Id., Ibid. 2001, L.I, P.IV, sec. VI, p. 286), e pela qual ele procurará encontrar os fundamentos da ciência moral e política.

Voltemos, então, relembrado o contexto em que ela se dá, à caracterização de nossas ações voluntárias e à questão da liberdade e da necessidade nela implicada, assim como ela nos foi apresentada neste livro sobre as paixões.

Desde o início, e pela própria natureza da investigação que 
então se desenvolve, o caminho escolhido por Hume para "melhor compreensão da natureza da vontade" não poderia ser o de uma análise da vontade como faculdade da alma. Com efeito, e como ele explicitamente dirá mais tarde, na Investigação, "pareceria, na verdade, que os homens principiam pelo lado errado da questão da liberdade e da necessidade, ao iniciar seu tratamento examinando as faculdades da alma, a influência do entendimento e as operações da vontade. Eles deveriam discutir, em primeiro lugar, uma questão mais simples, a saber, as operações dos corpos e da matéria bruta" (Hume 2004, p. 134). O que, como sabemos, Hume efetivamente fará, tanto no Tratado quanto na Investigação.

Trata-se, portanto, de recuperar a caracterização anteriormente feita das operações dos corpos, segundo os princípios de associação enunciados, e que acabara por ressignificar a necessidade que se reputava às relações da matéria e, por extensão, ressignificar a liberdade reputada às ações do espírito. De fato, segundo a análise desenvolvida por Hume no Livro I e retomada agora, nosso conhecimento dos corpos e de suas ações fundamenta-se na relação de causalidade. No entanto, como sabemos, se bem examinarmos tal relação teremos de reconhecer que ela não provém de um conhecimento da "essência ou estrutura" dos corpos, mas da união constante entre determinados eventos físicos, o que apreendemos pela experiência, e pelo hábito de nossa mente em, dado um desses eventos, inferir aquele a ele constantemente unido no passado, e acreditar em sua existência. É, portanto, a esta conjunção constante entre eventos e a uma inferência da mente que se resume a necessidade que reputamos existir nas ações da matéria. E é nesse sentido que, se for constatada esta mesma conjunção e inferência entre os motivos e ações do homem, ficará estabelecida, também aqui, a mesma necessidade.

Em todos os casos passados que pudemos observar, o movimento de um corpo é seguido, por impulso, do movimento de outro corpo. É impossível à mente penetrar além disso. Dessa união constante, ela forma a ideia 
de causa e efeito e, por sua influência sente a necessidade. Ora, como há a mesma constância e a mesma influência naquilo que denominamos evidência moral, não precisamos de mais nada. O que resta só pode ser discussão verbal (Hume 2001, L. II, P. III, sec. II, p. 442).

De fato, a estratégia de Hume será, então, a de defender que, tudo bem examinado, as questões em torno da liberdade são inconsistentes, puro nonsense, ou simples querela verbal. Pois, ninguém que diz coisa com coisa jamais teria imaginado negar que a causalidade existente no universo dos objetos é aquela que se percebe na uniformidade das relações que eles mantêm uns com os outros, nem, tampouco, que as ações voluntárias dos homens não mantêm uma mesma relação de uniformidade com seus motivos, temperamentos e situações. São muitas as passagens em que Hume insiste neste ponto. Teóricos e homens de ação, filósofos, moralistas, religiosos, comandantes, príncipes, ninguém que observasse as ações dos homens ou que sobre elas tivesse alguma ascendência, negaria a constância dessas ações ou deixaria de contar com ela³, bem como, ninguém que refletisse sobre a necessidade, nos novos termos então propostos, poderia deixar de admitir que ela surge dessa mesma constânciał .

3 "Não há nenhum filósofo cujo juízo esteja tão preso a esse sistema fantástico da liberdade que não reconheça a força da evidência moral, e que não a tome como um fundamento razoável de suas ações, tanto na especulação quanto na prática. Ora, a evidência moral não é mais que uma conclusão acerca das ações dos homens, derivada da consideração de seus motivos, temperamentos e situações. (...) O mesmo raciocínio está presente na política, na guerra, no comércio, na economia (...). O príncipe que impõe uma taxa aos seus súditos espera sua aquiescência. O general que comanda um exército conta com um certo grau de coragem. O comerciante confia na lealdade e na habilidade de seu gerente. O homem que dá ordens para o seu jantar não duvida da obediência de seus criados. (...) Ora afirmo que quem raciocina desta maneira crê ipso facto que os atos da vontade decorrem da necessidade, e se o nega não sabe o que diz." (Hume 2001, L.II, P.III, sec. I, p. 441).

4 "Devemos mostrar agora que, assim como a união entre os motivos e as ações tem a mesma constância que a união entre quaisquer operações naturais, assim também sua influência sobre o entendimento é a mesma, determinando-nos a inferir a existência de uns da existência dos outros. Se assim for, não haverá nenhuma circunstância conhecida, que faça parte da conexão e produção das ações da matéria, e que não se encontre também em todas as operações da mente; por conseguinte, será um absurdo 
De resto, para Hume, negar essa necessidade seria afirmar um absurdo, o absurdo mesmo de relegar ao acaso as ações voluntárias dos homens, pois, uma vez que "a necessidade é parte essencial da causalidade, a liberdade, ao suprimir a necessidade, suprime também as causas, e é o mesmo que o acaso. Como normalmente se pensa que o acaso implica uma contradição, ou ao menos que é contrário à experiência, os mesmos argumentos podem sempre ser utilizados contra a liberdade ou livre-arbítrio" (Hume 2001, L.II, P.III, sec. II, p. 443).

Sabemos, no entanto, que o que está em jogo vai muito além de uma mera disputa verbal. Trata-se de uma disputa em torno de concepções bastante distintas do que sejam os métodos e objetos de uma investigação filosófica. O que o próprio tratamento da questão da liberdade, ou dos atos voluntários, por Hume, no contexto da causalidade física e, portanto, de sua nova definição da necessidade, parece confirmar.

Em sua análise sobre a nova definição de necessidade proposta por Hume, Lebrun (2006) já nos chamava a atenção para dois aspectos fundamentais desse pensamento, a saber, a instauração de uma nova episteme e de um determinismo que poria por terra qualquer pretensão humana ao livre-arbítrio. Trata-se de uma nova consideração do comportamento dos elementos da natureza e do comportamento humano que, na verdade, nada mais seria do que a consequência de uma crítica ao paradigma de uma ciência que se quer como a revelação de uma ousia própria às coisas, tanto quanto de uma moral que se quer como a revelação de uma vontade autônoma própria aos sujeitos. De um lado, teríamos uma ciência que pretenderia desvelar a causalidade real inerente à natureza e, de outro, justamente a suspensão dessa causalidade pela irrupção da vontade humana e pela instauração de um outro plano, distinto

manifesto atribuir necessidade àquelas e recusá-las a estas." (Hume 2001, L.II, P. III, sec. I, p. 440). 
do natural, o plano moral. No entanto, com a substituição da concepção de causalidade como uma conjunção real entre os eventos naturais pela noção de conjunção habitual, abandona-se a tese que interpreta esta causalidade segundo a ideia de um suposto poder que estaria além do próprio fenômeno das relações observáveis entre os objetos, e que seria aquele mesmo da realidade metafísica da matéria - causa real desses fenômenos. É este poder, ou suposta realidade metafísica da matéria que onera as operações dos corpos, e que, por consequência, onera as ações da mente. Com efeito, na medida em que agimos, sem nos sentirmos forçados por este poder, nos compreendemos ou agindo na ausência de qualquer constrangimento, ou sendo capazes de resistir a qualquer constrangimento por um poder oposto, em outras palavras, ou nos sentimos agindo indiferentemente ou segundo um poder inato do sim e do não justamente, as duas concepções de liberdade da tradição metafísica que Hume pretende substituir. De resto, como ele já havia notado, "enquanto se supõe irrefletidamente que temos alguma ideia adicional de necessidade e de causação nas operações dos objetos externos, e, ao mesmo tempo, que não conseguimos descobrir tal coisa nas ações voluntárias da mente, partimos de uma suposição errônea que não permite levar a questão a uma conclusão definida". É assim que a nova definição de necessidade, enquanto conexão habitual entre eventos físicos, espera revelar, no campo da moral, o quanto a noção de necessidade inflacionada com a noção de conexão real gera uma reação despropositada, a saber, justamente a postulação da total falta de necessidade que seria própria às ações voluntárias do homem. É assim, ainda, que a nova definição de necessidade da física, desonerada de sua interpretação metafísica, revela-se extensível ao comportamento humano ao mesmo tempo em que desvela a falácia da liberdade.

De fato, a formulação da questão da liberdade sob o paradigma da causalidade física, imprime um sério deslocamento na discussão, então bastante dominada pelos cartesianos que, por sua vez, encontravam-se ainda influenciados pela disputa esco- 
lástica, entre molinistas e jansenistas. ${ }^{5}$ E Hume tem consciência da novidade por ele proposta, ainda que, aparentemente, procure minimizá-la. Com efeito, ao se referir às razões comumente apresentadas pelos defensores do livre-arbítrio, a primeira considerada é justamente aquela que se remete à consciência que temos, quando agimos voluntariamente, de não estarmos sendo constrangidos por nenhuma força, o que parece ser comprovado pela consideração, que então fazemos, de que poderíamos ter agido de outra forma. Consideração que, por sua vez, só se confirma se, posteriormente à ação, e ao nos voltarmos a considerá-la, agimos em outro sentido. No entanto, mesmo desconsiderados quaisquer outros motivos relativos a essa mudança de atitude, não podemos desconsiderar que a simples intenção de provar que poderíamos agir de outro modo constitui-se como um motivo, o que invalida a prova que esperávamos ter apresentado.

5 Remetemos o leitor à recuperação do embate entre jansenistas e molinistas, no contexto da caracterização da liberdade em Descartes, feita por Laporte: "A liberdade (...) se define à maneira molinista, como um poder de agir ou de não agir, necessariis ad agendum constitutis amnibus. É este poder que chamamos de independência (inalligatio), ou, ainda, indiferença. É preciso, no entanto, distinguir duas formas de indiferença: a indiferença de propensão ou inclinação, que comporta o equilíbrio da vontade, sem um agenciamento maior num sentido que no outro (assim como quando dois caminhos igualmente bons nos conduzem aonde queremos ir; e a indiferença de escolha, que comporta o poder de nos decidirmos por um dos partidos contrários, mesmo quando somos atraídos muito mais fortemente na direção do outro. Nesse sentido é preciso, ainda, distinguir também dois tipos de determinação: a determinação absoluta que, sendo possível, mesmo por ficção, imaginá-la dominando a vontade, suprimiria inteiramente qualquer espécie de indiferença; e a determinação relativa - advinda da concupiscência, das paixões, dos hábitos, enfim, de todas as influências pelas quais a alma é considerada "determinada" -, que nunca suprime ex toto o poder de escolher o contrário e deixa, sempre, a despeito do equilíbrio, subsistir a indiferença de escolha. É por essa distinção que se refuta a objeção de Jansenius: não são livres aqueles que, como o Cristo, os bem-aventurados ou os danados, são infalivelmente levados, uns ao bem, os outros ao mal? E, no entanto, não são eles desprovidos de indiferença? A resposta é que, na verdade, eles perderam a indiferença de inclinação, uma vez que sua inclinação se dirige totalmente para um dos lados; nem por isso eles conservam menos a outra indiferença, ou o poder de se desviarem dele, se o quiserem, segundo a máxima do Concílio de Trento (...). Esta indiferença existe no livre-arbítrio, tão fortemente fixada e confirmada tanto pelo bem, quanto pela natureza, ou por qualquer ajuda sobrenatural, como no caso dos bem-aventurados e dos anjos. (...) a vontade conserva este poder mesmo quando ela se encontra em um estado no qual é absolutamente certo que ela nunca irá usá-lo." (Laporte 1937, p. 131.) 
"Sentimos que nossas ações, na maioria das vezes, estão submetidas a nossa vontade; e imaginamos sentir que a vontade, ela mesma, não está submetida a nada - porque, quando, diante da negação disso, vemo-nos incitados a pô-lo à prova, sentimos que nossa vontade se move facilmente em todas as direções, produzindo uma imagem de si própria até mesmo ali onde ela não se estabeleceu. Convencemo-nos de que esta imagem, ou movimento fraco, poderia ter-se completado na própria coisa; porque, se isto também for negado, descobrimos ao tentar uma segunda vez que este é realmente o caso. Mas esse esforço é todo em vão. Por mais caprichosas e irregulares que sejam as ações que então pratiquemos, como o desejo de mostrar nossa liberdade é seu único motivo, nunca poderemos nos libertar das amarras da necessidade." (Hume 2001, L. II, P. III, sec. II, p. 444).

Sendo assim, o simples exame de nossas ações voluntárias, segundo a nova definição de necessidade proposta por Hume, parece ser suficiente para mostrar que a necessidade está sempre presente, ao mesmo tempo em que revela a sobrequalificação que costumamos fazer dessa necessidade onerando-a com a sensação de atuação de uma força ou constrangimento. Pois o que constamos neste caso senão a existência de relação entre ações e motivos sem a referida sensação de constrangimento?

Será, portanto, neste sentido, o de defender que sua hipótese é a única que permanece em pé diante da insustentabilidade e incongruência das hipóteses metafísicas sobre a liberdade, que Hume se remete, explicitamente, à distinção de escola entre a liberdade de indiferença - aquela que comporta o equilíbrio da vontade - e a liberdade de espontaneidade - que comporta o poder dos opostos.

Segundo esta mesma tradição, e para além de suas controvérsias, seria preciso distinguir, por um lado, entre a liberdade em seu mais baixo grau, característica da situação em que a vontade, não estando inclinada nem no sentido de qualquer paixão, nem, tampouco, por falta de iluminação ou ilustração, no sentido do 
bem e da verdade, se encontrasse indiferente e se exercesse segundo esta mesma indiferença. Por outro lado, haveria a liberdade de espontaneidade ou de escolha, pela qual nossa vontade seria livre em mais alto grau, e na qual, efetivamente, a responsabilidade moral seria fundada, uma vez que esta seria a situação em que, mesmo estando inclinada no sentido das paixões ou, ao contrário, no sentido do bem e da verdade, a vontade poderia se exercer em oposição a sua própria inclinação, poderia, efetivamente, escolher, uma vez que, mesmo sob influência, não estaria submetida a qualquer constrangimento.

E será justamente utilizando esta distinção da tradição metafísica, entre duas definiç̧ões de liberdade, que Hume chamará atenção, contra a própria tradição, para o problema do acaso e para a dificuldade em sustentar, nos termos propostos pela tradição, uma definição de liberdade que não se resuma a este mesmo acaso ou que, em contrapartida, não redunde na necessidade por ele, Hume, proposta.

Pois, como vimos, se considerarmos a liberdade de indiferença, segundo a qual a vontade não é movida por nenhum motivo, nenhuma situação, nenhum traço de caráter do agente, como distinguir esta indiferença do mero acaso? Mas se, ao considerarmos nossa liberdade de espontaneidade, passarmos a levar em conta, então, a existência de motivos, traços de caráter e situações que efetivamente inclinam a vontade e, mesmo assim, considerarmos que ela se exerce acima de qualquer um destes motivos, para além de qualquer inclinação, como não recair no acaso anterior? Pois, se não agimos por nada que nos incline, nem guiados pelo entendimento, nem pelas paixões, não agimos, justamente, indiferentemente? É assim que, como veremos, quando Hume parece estar interessado em preservar a liberdade de escolha, contra a liberdade de indiferença, é justamente tudo o que inclina a vontade no sentido de uma ação que ele tem interesse em preservar, e não o poder de, consideradas todas essas circunstâncias, agir para além delas. 
Tudo bem considerado, Hume nos chama a atenção para o fato de, levados pela consciência que temos, segundo nossa liberdade de espontaneidade, de podermos agir contra uma determinada tendência, ou, em outras palavras, de não sermos forçados a agir por esta tendência, acabarmos por nos confundir e afirmar a total ausência da atuação de qualquer tendência, a afirmarmos a liberdade de indiferença ou o acaso.

Poucos são capazes de fazer uma distinção entre a liberdade de espontaneidade, como é chamada na escolástica, e a liberdade de indiferença, ou seja, entre aquilo que se opõe à violência e aquilo que significa uma negação da necessidade e das causas. O primeiro sentido da palavra é o mais comum; e, uma vez que é somente essa espécie de liberdade que nos interessa preservar, nossos pensamentos têm se voltado sobretudo para ela, confundindo-a quase sempre com a outra (Hume 2001, L.II, P.III, sec. II, p. 443).

Se, no entanto, Hume consegue contemporizar com a tradição e manter uma aparência de acordo e, com isso, a estratégia em sustentar que, no fundo, todos dizemos a mesma coisa, a discordância abissal de projetos se revela por pouco que nos aprofundemos na metafísica que sustenta as caracterizações de liberdade que ele põe em jogo. Com efeito, a liberdade, para a tradição, continua dizendo respeito à vontade concebida como faculdade da autonomia do homem, e que, nesse sentido, diz respeito àquilo que, no homem, mais o torna semelhante a sua origem divina. Nesse sentido, as questões que então se levantam não se reduzem à suspensão ou não da necessidade constatada na natureza diante de uma suposta autonomia da vontade humana. Na verdade, parte-se dessa suspensão e dessa autonomia para enfrentar questões metafísicas de fundo teológico. De fato, as questões aqui dizem respeito à compatibilidade entre as duas faculdades que são postas como essenciais ao homem, a saber, entre a autonomia da vontade e a do entendimento, ou seja, ao poder da vontade de se exer- 
cer contra o esclarecimento do entendimento ${ }^{6}$ no sentido do bem e da verdade, e abraçar o caminho das paixões, dos hábitos, das necessidades do corpo, enfim, de todas as influências pelas quais a alma é considerada "determinada" do exterior. Mas, sobretudo, diz respeito ao problema de a vontade humana manter sua autonomia diante da vontade divina, ou seja, diz respeito ao problema da compatibilidade entre o livre-arbítrio e a providência divina. Em uma palavra, os problemas levantados pela questão da liberdade na tradição metafísica cristã dizem respeito à causalidade sobrenatural; contexto bastante distinto daquele em que a colocará Hume, ao abordar a questão da liberdade segundo a causalidade física. É assim que, justamente por fazer parte deste contexto teológico que Hume acaba de abandonar, a liberdade, enquanto indiferença da vontade ou poder de opostos parece pouco afetada pelo plano lógico das contradições apontadas por Hume.

Por outro lado, longe desse contexto, em última instância teológico, o que Hume entende ter diante de si, quando observa as ações voluntárias dos homens, não é a manifestação de um poder de escolha entre inclinações opostas, mas a simples oposição de inclinações, que se constituem em tendências, que se enfrentam até que a ação decorra daquela tendência mais forte e que então se impõe. É nesse sentido, nos parece, que as ações voluntárias, para Hume, são aquelas decorrentes justamente de um confronto, uma guerra entre motivos: não há arbítrio ou decisão exterior ao conflito - nele, ganha o mais forte. Hume entende, portanto, que essa oposição a determinadas inclinações, desprovida de sua interpretação metafísica ou teológica, não remete mais a uma essência do homem que seria distinta dessas mesmas inclinações - que são constituídas por traços de caráter, necessidades, paixões, situação -, mas a outras tantas inclinações, traços de caráter, necessidades, paixões, situações que constituem outras tendências que acabam 
por compor o todo que é o próprio agente. Agente e ação que, portanto, não excluem diferentes graus de oposição entre motivos e, portanto, a atuação mesma desses motivos. É assim que, reinterpretando a liberdade de espontaneidade da escolástica, Hume parece entender que, agir em oposição à determinada tendência não significa um poder de agir livre de qualquer tendência, mas, antes, a relação existente entre determinada ação e uma determinada tendência, encontrada em um sujeito - sujeito que nada mais é do que o todo composto por essas mesmas tendências, sejam elas conformes umas às outras ou opostas.

Caminhando nesta direção, somos fortemente tentados a afirmar que, para Hume, as ações voluntárias são a exteriorização mais fidedigna dos agentes, não no sentido em que estes agentes possuem uma interioridade a ser exteriorizada, mas no sentido em que elas são aquelas ações que provêm dos agentes considerados em sua maior complexidade possível, ou seja, como um conjunto de motivos, traços de caráter e hábitos em distintas situações, configurando tendências que ora se confirmam e ora se opõem, em um movimento constante.

No entanto, tal afirmação pode facilmente ser considerada abusiva se nos ativermos a letra mesma de algumas passagens do texto de Hume e ao movimento argumentativo por ele desenvolvido.

Com efeito, o projeto de Hume de "introduzir o método experimental de raciocínio nos assuntos morais", evidencia-se em toda sua força e abrangência nesta inserção da questão da liberdade no contexto da causalidade física, que, ao substituir o contexto da discussão metafísica sobre o tema, passa a discuti-la segundo um paralelismo estrito daquilo que se observa nos eventos da matéria e da mente, ou seja, a união constante entre estes eventos e a inferência da mente, da apresentação de um, à existência do outro, em outras palavras, a necessidade de suas relações.

No entanto, e aqui o ponto de inflexão de nossa tentação anterior, esta relação entre eventos físicos e entre motivos e ações é, por princípio, considerada de um ponto de vista exterior. De 
fato, do mesmo modo em que a necessidade da matéria é, stricto sensu, exterior à própria matéria, na medida em que é um hábito de um observador exterior que, certamente, leva em consideração a constância dos eventos materiais, mas que vai além deles, assim também devemos considerar a necessidade das ações voluntárias. E, quanto a isso, Hume é explícito: "A necessidade de uma ação, seja da matéria seja da mente, não é, rigorosamente falando, uma qualidade do agente, mas sim de algum ser pensante ou inteligente que possa considerar de fora a ação, consistindo na determinação de seu pensamento a inferir a existência dessa ação a partir dos objetos preexistentes" (Hume 2001, L. II, P. III, sec. II, p. 444). Sendo assim, do mesmo modo que consideramos que a necessidade da matéria só diz respeito a seus eventos observáveis, ou seja, que nada diga sobre uma sua suposta natureza íntima, também não consideramos que a necessidade das ações voluntárias diga algo sobre uma suposta natureza íntima do agente, mas apenas daquilo que é dele observável, associada a uma determinação na mente do observador dessas ações.

Tal é a perspectiva mesma da Ciência proposta por Hume e que se resume, em última análise, em uma capacidade de "prever" eventos a partir do recorte mais apurado possível de eventos passados, em outras palavras, com a capacidade de estabelecer regras gerais a partir da observação, exterior, dos eventos passados. É nesse mesmo sentido, de resto, que Hume responde ao argumento que vai contra a possibilidade de construir tal ciência no âmbito moral, ao chamar a atenção para o "capricho humano", contra toda constância observável do seu comportamento.

Com efeito, contra a constatação da conexão regular entre temperamento e situação do agente e suas ações, há a inegável constatação do capricho humano. "Pois o que é mais caprichoso que as ações humanas? O que é mais inconstante que os desejos do homem? E que criatura se afasta mais, não somente da boa razão, mas de seu próprio caráter e disposição? Uma hora, um instante é suficiente para fazê-lo passar de um extremo a outro, e 
destruir aquilo que custou tanto esforço e trabalho para construir. A necessidade é regular e certa. A conduta humana é irregular e incerta. Esta, portanto, não procede daquela." (Hume 2001, L.II, P.III, sec. I, p. 439). De fato, ainda que admitamos a nova noção de necessidade proposta por Hume, parece difícil aceitar que a relação entre motivos e ações humanas se dê no mesmo grau de regularidade em que se dá a conexão entre os eventos da matéria. Hesitamos, ainda, em aceder a que a regularidade que encontramos enunciada pela lei da gravidade, por exemplo, é a mesma que podemos encontrar na atitude de um homem diante de uma bolsa cheia de ouro, encontrada no meio da rua. E, efetivamente, não é isto que Hume nos diz quando afirma que "um homem que ao meio-dia deixe sua bolsa recheada de ouro na calçada de Charing-Cross pode tão bem esperar que ela voará para longe como uma pena como que a encontrará intacta uma hora mais tarde?" (Id., Ibid. 2004. p. 132).

É assim que, em resposta ao contra-argumento que chama a atenção para a irregularidade e incerteza das ações humanas, Hume mantém o ponto de vista da ciência e apela, como resposta, para o mesmo raciocínio com o qual a irregularidade na Natureza é explicada. De fato, a constatação de irregularidades nas ações da matéria, longe de levar o cientista a eliminar a noção de necessidade e de causalidade que fundam a crença e o conhecimento dos objetos, leva à consideração da existência de causas ainda desconhecidas e que deveriam ser procuradas.

Quando dois fenômenos se apresentam em uma conjunção constante e invariável, adquirem uma tal conexão na imaginação que esta passa de um a outro sem qualquer dúvida ou hesitação. Abaixo deste, porém, há diversos graus inferiores de evidência e probabilidade; uma única contrariedade na experiência não destrói inteiramente nosso raciocínio. A mente pesa as experiências contrárias e, subtraindo as inferiores das superiores, procede segundo o grau de segurança ou evidência que resta. Mesmo quando estas experiências são exatamente equivalentes, não su- 
primimos a noção de causa e de necessidade; supomos que a contrariedade usual decorre da operação secreta de causas contrárias, e concluímos que o acaso e indiferença se deve ao nosso conhecimento imperfeito e está apenas em nosso julgamento, não nas próprias coisas, as quais são igualmente necessárias em todos os casos, ainda que não apareçam de maneira constante ou certa. Nenhuma união pode ser mais constante e certa que a de algumas ações com determinados motivos e caracteres; se, em outros casos, a união é incerta, essa incerteza não é maior que a de algumas operações dos corpos. Não podemos extrair do primeiro tipo de irregularidade uma conclusão que não se siga igualmente do outro. (Hume 2001, L. II, P. III, sec. I, p. 440).

Do fato da constante conjunção entre dois eventos, A e B, cria-se, na mente, a expectativa de tal modo arraigada de que, uma vez ocorrido novamente o evento A, dele se seguirá o evento $\mathrm{B}$, que a força desta expectativa acaba por se traduzir na crença em uma relação necessária entre estes dois eventos, necessidade que se desdobra, por sua vez, na crença de que um evento seja a causa ou origem do outro. Quando, no entanto, esta uniformidade é quebrada por algum contra exemplo, admitimos, para além dos juízos indubitáveis, juízos apenas prováveis. No entanto, o fato de admitirmos um conhecimento fundado em graus de probabilidades não implica que duvidemos do princípio mesmo da causalidade. Prova disto é que reputamos tal irregularidade e os diferentes graus de probabilidade de nossos juízos ao nosso desconhecimento de outras causas também atuantes. É esta crença, em última análise, que funciona como incremento da investigação da ciência da matéria. Esta mesma crença vigora em relação às ações voluntárias e na Moral. De fato, se, das relações constantes existentes entre motivos, traços de caráter, situação e ações, e da inferência, feita pela mente, de que essa constância passada se repetirá no futuro, deriva a crença na necessidade dessas ações, segue-se que qualquer inconstância nestas ações da mesma forma será explicada pela atuação de causas desconhecidas ou não con- 
sideradas. Mais uma vez, portanto, não há como fugir da relação entre nossas ações e seus motivos, pelo que se forma a hipótese de que o conhecimento de todas essas causas levaria à total previsibilidade das ações.

Podemos imaginar que sentimos uma liberdade dentro de nós, mas um espectador comumente será capaz de inferir nossas ações de nossos motivos e de nosso caráter. E, mesmo quando não pode fazê-lo, geralmente conclui que poderia, caso estivesse perfeitamente familiarizado com todas as circunstâncias de nossa situação e de nosso temperamento e com os mecanismos mais secretos de nossa constituição e disposição. Ora, tal é a essência mesma da necessidade, conforme a doutrina anterior (Hume 2001, L. II, P. III. sec. II, p. 445).

Em outras palavras, segundo Hume, os diferentes graus de probabilidade nos quais se pautam, tanto nossa Física quanto nossa Moral se devem à maior ou menor acuidade empírica e, de resto, o próprio caráter probabilístico de nossa ciência se deve ao fato de nós, observadores limitados, jamais podermos nos acercar de todos os elementos implicados. Neste sentido, quanto mais dados arregimentamos, mais provavelmente certa nossa previsão é e, no limite, para uma inteligência que tivesse o conhecimento perfeito de todos os dados do problema, não haveria mais previsão provável, mas previsão certa. É assim que, quanto mais circunstâncias passadas e presentes pudermos levar em conta, tanto mais poderemos estabelecer a trama de relações da qual decorrerá a ação de um agente qualquer, com maior probabilidade poderemos prevê-la, tanto mais a necessidade a ela se aplicará.

No entanto, uma questão ainda se coloca. É possível manter este ponto de vista exterior, paradigmático da ciência da matéria, e seu ideal de previsibilidade, quando se trata da mente? Ou, melhor dizendo, a via da ciência é nosso único acesso ao universo mental?

E no sentido de desenvolver esta questão, entro em minhas considerações finais. 
Então, vejamos.

Como vimos, admitida a unidade da Física e da Moral, proposta por Hume, aparentemente admite-se o determinismo, ao menos aquele que nega a existência de um poder absoluto de escolha, no homem, e que afirma a existência de uma relação entre motivos e ações. A questão que se coloca é a de saber se, negando o livre-arbítrio, segundo o qual "de uma mesma série podem resultar atos diferentes, igualmente possíveis", e afirmando, ao contrário, que "a determinados antecedentes corresponde uma única ação", estamos também afirmando que, antes da ação realizada, conhecendo todos os seus antecedentes, de modo absolutamente exaustivo, podemos prever a ação que então deles se seguirá. Em outras palavras, admitir que há uma relação necessária entre motivos e ações é o mesmo que admitir a total previsibilidade destas? Pois, se assim for, de posse de todos os dados não há possibilidade para a surpresa. Se determinação das ações pelos antecedentes significa previsibilidade, então, determinação significa ausência de novidade possível no que diz respeito às ações voluntárias do homem.

Mas, aqui também, podemos recorrer ao textos. De fato, a previsão em questão não pode ser considerada stricto sensu, ou seja, não se trata propriamente de uma previsão, no sentido de uma visão prévia de tudo o que ainda não ocorreu, mas ocorrerá, necessariamente; trata-se, mais estritamente, de uma simples transposição do passado para o futuro, feita pelo observador exterior, e fundada mais na natureza desse observador, do que na dos próprios eventos. De resto, o próprio Hume já teria aberto mão da previsibilidade real ao abrir mão da própria noção de causalidade real, ao mostrar que não conhecemos os efeitos futuros pela simples inspeção da essência mesma daqueles eventos que consideramos como causas, mas que precisamos da experiência passada da conexão desses eventos com outros quando, só então, poderão assumir papel de causa e efeito.

Esclarecido este sentido de previsibilidade, segue-se que ele é adequado tanto à ciência moral quanto à ciência física, ou seja, 
que podemos pautar nossas ações, em relação à matéria, ou em relação aos outros homens, na crença de que o passado se repita no futuro, mas, nos parece, não se segue que nessa crença se resuma tudo o que pode ser dito sobre o universo mental.

E isto porque a própria complexidade do universo mental não o permite. Em primeiro lugar, se considerarmos que nosso conhecimento da matéria se funda em nossa experiência sensível, nas ideias que aí se originam e nos princípios que as associam, nosso conhecimento do universo mental, de início, já tem de ser considerado mais complexo, na medida em que abarca, também, todas as nossas afecções e paixões. Sofremos afecções de dor e de prazer, que implicam um corpo, que conhecemos pelas impressões sensíveis, as quais, por sua vez, não nos dão apenas os corpos exteriores, mas o nosso corpo próprio. Tais afecções se fazem acompanhar por impressões reflexivas, ou paixões, como o desejo e a aversão, a tristeza e a alegria, a esperança e o medo. Misturas destas impressões reflexivas com determinadas ideias são, por sua vez, acompanhadas pelas paixões indiretas, como "o orgulho, a humildade, a ambição, a vaidade, o amor, o ódio, a inveja, a piedade, a malevolência, a generosidade, juntamente com as que dela dependem". Somos impressionados, enfim, pelas associações passíveis de serem feitas entre estas impressões, contraímos hábitos, nos constituímos como tendência, assumimos traços de caráter. Em resumo, para além das impressões e ideias sensíveis, e de seus princípios de associação, pelo que concebemos os corpos, há todo o universo das afecções e das paixões que qualifica a mente em sujeito e diversifica o sujeito em um eu.

Mas, para além de toda essa complexidade própria ao universo mental, que envolve não apenas ideias como também toda a gama de afecções e paixões, há ainda que se considerar a diferença entre a associação própria às ideias e a própria às impressões.

Pois, se as ideias, em sua exemplar distinção, são associadas do exterior, o mesmo não pode ser dito das impressões, como o próprio Hume já observara: 
As ideias podem se comparar à extensão e à solidez da matéria; e as impressões, especialmente as reflexivas, às cores, sabores, odores e outras qualidades sensíveis. As ideias nunca admitem união total; ao contrário, são dotadas de uma espécie de impenetrabilidade, que faz que se excluam mutuamente, de modo que só são capazes de formar um composto por meio de sua conjunção, e não por sua mistura. As impressões e as paixões, por sua vez, são suscetíveis de uma união completa; como as cores podem se misturar tão perfeitamente que cada uma delas desaparece, e apenas contribui para modificar a impressão uniforme resultante do conjunto. Alguns dos fenômenos mais curiosos da mente humana decorrem dessa propriedade das paixões (Hume 2001, L. II, P. II, sec. VI).

O que temos aqui, senão a constatação, de duas dimensões qualitativamente diferentes da experiência, ainda que em constante relação? Aquela dimensão da experiência que é similar à da que temos da matéria, que se divide em partes impenetráveis, que mantêm entre si exterioridade recíproca e que só podem ser associadas por conjunção, mantendo-se justapostas, sem, portanto, sofrer qualquer mistura, qualquer alteração interna e, nessa medida, adequando-se mais a uma repetição do passado no futuro. A outra, aquela dimensão da experiência que temos de nossa própria mente, na medida em que as impressões sensíveis, que são sua origem, são matizadas de afecções e paixões cujas "partes”, ao se associarem, podem se misturar de tal modo que dessa mistura abre-se a possibilidade para o surgimento de algo novo.

É assim que, se considerarmos apenas as ideias e suas associações, segundo os princípios detectados por Hume, e nos quais se funda nossa ciência, o que existe é uma descontinuidade de partes que se associam do exterior - partes claras e distintas e associações estáveis - e, do lado das paixões, o que se configura é, antes, um contínuo. Com efeito, ao tratar das paixões diretas da esperança e do medo e de como elas surgem, a partir das afecções do bem e do mal, por um jogo entre as paixões da alegria e da 
tristeza com as ideias da imaginação, Hume mais uma vez chama a atenção para outra diferença entre ideias e impressões:

Ora, se considerarmos a mente humana, veremos que, no que diz respeito às paixões, sua natureza não é a de um instrumento de sopro, que, quando percorridas suas notas, perde imediatamente o som assim que cessa a respiração; assemelha-se, antes, a um instrumento de cordas, em que, após cada toque, as vibrações continuam retendo algum som, que se extingue gradual e insensivelmente(...) (Hume 2001, L. II, P. III, sec. IX, p. 476).

Se é assim, se no universo mental, no que diz respeito às paixões, há essa continuidade para além de uma origem pontual, e se, como vimos acima, há neste contínuo, mistura das impressões que o vão compondo, e não manutenção de parte extra partes que se relacionam do exterior, parece que só podemos explicar que a relação de causalidade se aplique ao universo mental, que a crença na repetição do passado se dê no plano mental, justamente quando, com intenções bem definidas, abandonamos nosso acesso interior a esse universo e adotamos um ponto de vista exterior. Quando estamos interessados nos hábitos adquiridos, nas noções do bom senso, nas ideias correntes, naqueles complexos de impressões e de ideias que respondem às necessidades mais gerais e mais constantes de todas as mentes em quaisquer circunstâncias. Não, portanto, quando estamos sendo impressionados, refletindo sobre essas impressões, sofrendo novas impressões e sendo levados a agir, mas quando revemos partes acabadas desse processo e passamos a narrá-las, quando somos os historiadores de nosso passado. Quando nosso interesse é encontrar padrões nesse contínuo que é o da guerra entre paixões fracas e violentas, estabelecer regras gerais, que torne possível influir sobre ela, aplacá-la. Quando fazemos a Ciência da Natureza Humana com vistas a estabelecer uma Moral, uma Política. Quando, por fim, assumindo a posição dos filósofos temos de "abrir mão de todas as revoltas menores e 
mais delicadas, por dependerem de princípios demasiadamente sutis e diminutos para compreensão" (Hume 2001, L. II, P. III, sec. X., p. 485).

Nesse sentido, portanto, a dificuldade em reunir todas as causas envolvidas em um processo, uma vez que ela é tanto maior quanto mais "humana" é a ciência em questão, parece não se dever pura e simplesmente ao seu caráter sutil e diminuto, mas, antes, àquilo mesmo que este caráter sutil e diminuto significa, a saber, uma experiência cada vez mais própria e individual e que, no que diz respeito ao universo mental, se afasta, e não se aproxima, da realização do ideal de ciência. Quanto se trata da mente, são as visões à distância que produzem ciência, e não a acuidade da visão, do recorte do campo experimental que caracteriza um indivíduo.

Voltemos, então, para nossa questão anterior, a saber: é possível manter o ponto de vista que tem como paradigma a ciência da matéria quando se trata da mente, em outras palavras, é possível manter este ponto de vista ao mesmo tempo exterior e maximamente detalhista, que considera a mente como dividida por partes com exterioridade recíproca e espera poder prever suas ações com o recenseamento exaustivo dessas partes?

Com efeito, nos parece que se quiséssemos reunir todos os elementos referentes a determinada ação de um sujeito ainda não realizada, no sentido de poder determiná-la com certeza, seria preciso se confundir com o próprio agente e abandonar, definitivamente, o posto de observador universal. Pois, não sabendo de antemão qual detalhe da vida dessa pessoa teve influência ou foi mais determinante na realização da ação, o que só se evidenciará uma vez realizada a própria ação, teríamos de percorrer todos e cada um dos ínfimos detalhes que a compõem. Teríamos, portanto, de conhecer cada afecção de dor e prazer, de mal e de bem, todas as impressões sensíveis, nelas incluídas não apenas as situações de tempo e lugar, só passíveis de serem vividas por um determinado corpo próprio, bem como de todas as impressões re- 
flexivas, ou paixões delas decorrentes, na gama de intensidades em que elas se apresentassem, bem como da "mistura entre elas", e, finalmente das tendências a elas imprimidas pelo caráter de um sujeito já constituído. E, se assim for, ao percorrer todas essas circunstâncias, acabaríamos por chegar ao momento mesmo da realização da ação, e não a sua previsão, na "pele" do próprio agente. ${ }^{7}$

O que concluir disto senão que, se a ciência que diz respeito às ações voluntárias se configura nos moldes da ciência da matéria, ou seja, se tais ações podem ser consideradas segundo a causalidade física, disso não se segue um determinismo estrito - o que é confirmado, não apenas pela própria concepção de causalidade colocada em jogo por Hume como por sua compreensão do processo das paixões - mas, antes, no abandono do paradigma da decisão pelo paradigma da trama das circunstâncias. Com efeito, que nossas ações sejam a decorrência de circunstâncias anteriores, não decorre que possamos prever essas ações, uma vez que só temos acesso a essas circunstâncias do interior, experimentando-as em nós mesmos, e não como observadores exteriores. É assim que, se podemos dizer, com os deterministas que "a determinados antecedentes correspondem uma única ação", disso não se segue que possamos saber qual ação é esta, antes que ela ocorra.

Por outro lado, não se trata mais de remeter a responsabilidade das ações a uma única instância decisória e gastar todos os nossos esforços para descobrir o bem e a verdade que, enfim, deve determinar a própria vontade no sentido da decisão certa. Trata-se de se remeter às circunstâncias, de bem distinguir aquelas que são passíveis de serem distinguidas, de considerar os melhores meios em vista do alcance dos fins perseguidos, mas, sobretudo, compreender que estes fins são as próprias paixões, e, sendo assim, agir ou reagir às paixões da única maneira possível, temperando-

7 Cf. exaustiva crítica de Bergson ao determinismo no terceiro capítulo do Ensaio. Ver Ref. Bibliográfica. 
-as, cultivando aquelas que, por fim, podem nos ajudar a realizar aquela que nos move mais intensamente, a saber, a paixão pela vida em comum.

De fato, nos diz Hume, o homem é "dentre todas as criaturas do universo, a que tem o desejo mais ardente de sociedade e está preparada para ela pelo maior número de circunstâncias favoráveis. Somos incapazes de formar um desejo sequer que não se refira à sociedade. (...) Quaisquer que sejam as outras paixões que possam nos mover - orgulho, ambição, avareza, curiosidade, vingança ou luxúria -, a alma ou o princípio que anima a todas elas é a simpatia."

É assim que, nos parece, o interesse moral e político justifica a inclusão do sujeito no âmbito da ciência, bem definido nosso conceito de ciência e bem resguardada a complexidade do sujeito que vai além desse seu papel de objeto de uma ciência.

Em suma, se a inclusão da questão das ações voluntárias no âmbito da causalidade, pelo paralelismo proposto por Hume, entre a física e a Moral não passa de simples boutade, e se constitui como novo paradigma para o tratamento da questão da liberdade, é justamente porque ela não remete mais a um suposto poder do sim e do não, constitutivo de um sujeito teórico, tampouco remete a um sujeito que é apenas parte de um encadeamento causal desde já dado e, por isso, passível de ser absolutamente previsto, mas, ao contrário, à própria complexidade, da qual não se descarta a real imprevisibilidade, da trama de impressões que constitui o sujeito prático e social.

\section{Bibilografia}

BERGSON, H. Essai sur les donnés imédiates de la conscience. Édition critique sous la diréction de Frédéric Worms. Paris: PUF, 2007. 
DELEUZE, G. Empirisme et subjectivité. PARIS: PUF, 2007.

HUME. D. A Treatise of Human Nature. Selby-Bigge/Nidditch (eds.). Oxford: Clarendon Press, 1989. Tradução para o Português de Déborah Danowski. São Paulo: UNESP - Imprensa Oficial, 2001. . An Enquiry concerning Human Understanding. Selby-Bigge/Nidditch (eds.). Oxford: Clarendon Press, 1992. Tradução para o português de José Oscar de Almeida Marques. São Paulo: UNESP, 2004.

LAPORTE, J. “La liberté selon Descartes”. In: Revue de Métaphysique et Morale, 44(1), 1937.

LEBRUN, G. "A boutade de Charing-Cross". In: A Filosofia e sua História. São Paulo: CosacNaify, 2006. 